\title{
BÓG I CZłOWIEK W BIBLIJNEJ HISTORII JÓZEFA (RDZ 37-50)
}

Cykl przekazów poświęconych życiowym perypetiom Józefa i jego braci (Rdz 37-50) należy do najpiękniejszych i najkunsztowniejszych świadectw literatury biblijnej ${ }^{1}$. Końcowe rozdziały księgi Rodzaju są jednocześnie kompozycją niezwykle oryginalną i złożoną, która nosi na sobie ślady licznych teologicznych korekt. Historia Józefa została bardzo misternie wkomponowana w obszerną sagę o rodzie Jakuba $(25,21-50,26)$ tak, że dziś z jednej strony stanowi wyraźne zwieńczenie bardzo długiej opowieści o protoplastach Izraela ( $R d z 12-50)$, natomiast z drugiej zdecydowanie odróżnia się od poprzednich bloków księgi, których głównymi bohaterami są kolejno: Abraham (11,27-25,18), Izaak, Jakub $(25,19-35,29)$ i Ezaw (36,1-43). Porównując tekst Rdz 37-50 z tymi zbiorami tradycji, dostrzega się bardzo wiele literackich i teologicznych różnic. Najbardziej widoczną i charakterystyczną jest tematyczna jednorodność i spójność oryginalnego trzonu relacji o Józefie, której brakuje w złożonych z dość luźnych przekazów kolekcjach o Abrahamie i Jakubie. Na szczególną uwagę zasługuje na przykład specyficzna rola, jaką autor tego cyklu przypisuje Bogu Jahwe. Bóg

${ }^{*}$ Ks. dr hab. Dariusz Dziadosz, adiunkt przy Katedrze Ksiąg Historycznych i Dydaktycznych na Katolickim Uniwersytecie Lubelskim Jana Pawła II oraz rektor Wyższego Seminarium Duchownego w Przemyślu.

${ }^{1}$ M. Savage, Literary Criticism and Biblical Studies. A Rhetorical Analysis of the Joseph Narrative, w: C. Evans, W. Hallo, J. White, Scripture in Context, Pittsburgh 1980, s. $79-100$. 
Abrahama, Izaaka i Jakuba, który w poprzednich zbiorach był wszechobecny i nieustannie decydował o biegu zdarzeń, w przekazach o Józefie niespodziewanie traci swą pierwszoplanową pozycję i pozostaje prawie niewidoczny. Miejsce Boga w historii Józefa zajmują bohaterowie ludzcy i to zarówno ci pozytywni, jak i negatywni. Jeśli bowiem z aktualnej wersji cyklu wyłączymy epizody opisujące relację Józefa z żoną Potifara $(39,1-20)^{2}$ i zarządcą więzienia $(39,21-23)$, wizję (mar’ōt), której patriarcha Jakub doświadczył w Beer Szebie $(46,1-5 a)^{3}$, oraz kilka innych pomniejszych glos teologicznych wyjaśniających religijny podtekst toczącej się akcji opowiadania $(45,5-9 ; 50,20)$, to w jego obrębie nie pozostanie już żaden tekst, w którym Bóg występowałby w roli głównego bohatera narracji i decydował o biegu wydarzeń. W kolejno odsłanianych epizodach historii Józefa Jahwe pojawia się zazwyczaj tylko pośrednio. Zwykle ma to miejsce jedynie w teologicznych konstatacjach narratora lub w kluczowych dialogach głównych bohaterów narracji. Ze zrozumiałych względów imię Jahwe gości najczęściej na ustach Józefa ${ }^{4}$. Wniosek ten jest znaczącym powodem, dla którego na pierwszy rzut oka można byłoby sądzić, iż wola Jahwe i Jego plan zbawienia wcale nie są głównym wątkiem opowiadania, a lektor tych tradycji na równi z ich bohaterami jest zmuszony do mozolnego i stopniowego odkrywania zamysłów Boga w oparciu o kolejno relacjonowane epizody i fakty.

Czy jednak oznacza to, że teksty o Józefie mają charakter świecki i należy umieścić je w jednym szeregu z tradycjami o antycznych i mitycznych herosach, którzy dzięki męstwu oraz wrodzonej przebiegłości i zręczności potrafili wychodzić nawet z najcięższych opresji i przyczyniali się do wyzwolenia całych społeczności? Czy można przypuszczać, że dopiero jeden z ostatnich redaktorów księgi Rodzaju nadał historii Józefa wymiar teologiczny, wkomponowując w pierwotnie laicki przekaz teksty, które podkreślały decydującą rolę Boga w opisywanych zdarzeniach i kontynuowały teologiczny wątek obecny we wcześniejszych cyklach o Abrahamie i Jakubie? A może mamy tu raczej do czynienia $\mathrm{z}$ bardzo oryginalnym sposobem pisania historiografii biblijnej,

${ }^{2}$ W perykopie tej Boże imię yhwh (’ādōnāy) występuje w 39,2.3 (2 razy) .5 (2 razy) .21.23. Prócz tego, w wierszach tych spotykamy też termin è̉ohhîm (Bóg). Następuje to w chwili, w której Józef odwołuje się do Boga w dialogu z pogańską małżonką swego pana $(39,9)$.

${ }^{3}$ Trzeba pamiętać, że jest to jedyna tego rodzaju wizja, o jakiej mówi cały zbiór tradycji o Józefie. Jakże odmienną jest sytuacja naszkicowana w cyklach poprzednich, w których Bóg bezpośrednio i bardzo często zwracał się w ten sposób do patriarchów. Warto też zauważyć, że odbiorcą Bożego objawienia w cyklu o Józefie nie jest główny bohater, ale jego ojciec Jakub (por. 28,12-15; 32,25-30).

${ }^{4}$ Por. 39,$9 ; 40,8 ; 41,16.25 .28 .32 .38 .39 .51 .52 ; 42,18.28 ; 43,14.23 .29 ; 44,16 ; 45,5.7 .8 .9 ; 46,3$; 48,3.9.11.15.20.21; 49,18.25; 50,17.19.20.24.25. W niektórych z tych wierszy imię Boga występuje dwukrotnie, w sumie mamy do czynienia z 34-krotnym użyciem Bożego imienia w różnorodnych formach: yhwh (’ādōnāy) (Jahwe, Pan), è̉lōhîm (Bóg), ’ēl šadday (Bóg mocny, wszechmogący). Aż 20 ze wszystkich tych odniesień do Boga pojawia się na ustach Józefa. 
w którym nadprzyrodzona aktywność Jahwe przez większą część relacji zostaje świadomie i programowo usunięta w cień po to, aby ukazać niezbadaną głębię ludzkich wyborów, zachowań i motywacji. Jedno jest bowiem pewne. Mimo wielkiego nacisku, jaki autor tych tekstów kładzie na aspekt ludzkich motywacji i emocji, należy zauważyć, że w cyklu o Józefie i jego braciach Bóg dochodzi do głosu we wszystkich momentach kluczowych, tak iż w perspektywie całej kompozycji nie ma żadnych wątpliwości, że to, co się dzieje, nie jest ślepym trafem, lecz logiczną konsekwencją woli Jahwe, który niejako z ukrycia kieruje losem głównych bohaterów. Zadaniem niniejszego artykułu będzie pogłębiona analiza tej bardzo interesującej kwestii, którą podejmiemy na tle gruntownego badania literackiej i teologicznej specyfiki zbioru tradycji Rdz 37-50.

\section{LITERACKA CHARAKTERYSTYKA CYKLU PRZEKAZÓW O JÓZEFIE}

Pierwszą zasadniczą kwestią do rozwiązania w przypadku zbioru tradycji o Józefie jest problem jego granic oraz literackiej i teologicznej odrębności. Chodzi o to, czy w kontekście obszernych przekazów o patriarchach Izraela (Rdz 12-50) należy mówić o ściśle określonej i tematycznie autonomicznej kolekcji tekstów, którą potocznie nazywa się historią Józefa, czy też raczej tylko o jednym z komponentów rozległej sagi o Jakubie $(25,19-50,26)^{5}$. Literacka i teologiczna specyfika tych tekstów nie pozostawia wątpliwości. Począwszy od wiersza $37,2^{6}$ aż do końca księgi $(50,26)$ mamy do czynienia z wyraźnie wyodrębnioną kompozycją o jasno sprecyzowanym wątku tematycznym. Styl tej kompozycji przypomina antyczną nowelę lub sagę ${ }^{7}$ a jej rdzeń, który prawdopodobnie stanowił pierwotnie niezależny dokument literacki ${ }^{8}$, jest opowieścią o barwnych

${ }^{5} \mathrm{Na}$ tę ostatnią ewentualność wskazuje zarówno początek (37,1-2, por. analogiczne otwarcie cyklu o Jakubie w 25,19 nawiązujące do jego ojca Izaaka), jak też zakończenie cyklu $(47,27-50,13)$. Obydwa te teksty stanowią ewidentną literacką klamrę łączącą dzieje Józefa $\mathrm{z}$ historią patriarchy Jakuba. H. Seebass, The Joseph Story, Gen 48 and the Canonical Process, JSOT 35 (1986) s. 29-43.

${ }^{6}$ Wiersz ten wydaje się pełnić $\mathrm{w}$ tym miejscu rolę tytułu nowej literackiej sekcji wchodzącej w skład większej kompozycji literackiej, którą w tym wypadku jest historia patriarchów (por. 11,27; 25,19).

${ }^{7}$ G. W. Coats, Another Formcritical Problem of the Hexateuch, Semeia 46 (1989), s. 65-73; tenże, Redactional Unity in Genesis 37-50, JBL 93 (1974), s. 15-21; B. Dahlberg, On Recognizing the Unity of Genesis, TD 24 (1976), s. 360-367; W. Humphreys, Novella, w: G. W. Coats, Saga, Legend, Tale, Novella, Fable (JSOT.S 35; Sheffield 1985), s. 82-96; O. Kaiser, Stammesgeschichtliche Hintergründe der Josephsgeschichte. Erwägungen zur Vor und Frügeschichte Israels, VT 10 (1960), s. 1-15; A. Mainhold, Die Gattung der Josephsgeschichte und des Estherbuches. Diasporanovelle, ZAW 88 (1976), s. 72-93; L. Ruppert, Zur neueren Diskussion um die Josephsgeschichte der Genesis, BZ 33 (1989), s. 92-97.

${ }^{8}$ Wielu egzegetów widzi w tym pierwotnym przekazie o Józefie kompozycję o bardzo precyzyjnej (koncentrycznej) strukturze. G. Wenham, Genesis 16-50 (WBC 2; Dallas 1994), s. 344. 
perypetiach Józefa i jego braci (37.39-47). Z biegiem czasu ten oryginalny dokument literacki został poszerzony o materiał dotyczący innych patriarchów (np. 38,1-30, 49,1-28) i przy pomocy takich teologicznych tekstów jak 50,24-25, został wkomponowany w obręb historii Jakuba i nurt pozostałych tradycji o protoplastach Izraela ( $\mathrm{Rdz} 11,27-36,43)$. Dzięki tym redakcyjnym interwencjom, aktualna wersja historii Józefa stała się w kontekście wcześniejszych tradycji o patriarchach rozbudowaną biblijną relacją o wierności Jahwe wobec rodu Jakuba. Jak podaje bowiem jej treść, Bóg uratował przez Józefa od plagi głodu nie tylko cały jego dom, ale też inne narody. A według aktualnej teologicznej struktury księgi Rodzaju Jahwe uczynił to ze względu na uroczyste obietnice, które złożył Abrahamowi (zobowiązanie Boga, iż będzie błogosławił ludom ze względu na potomstwo Abrama w 12,3). Wkomponowanie tradycji o Józefie w historię rodu Jakuba miało też inny bardzo ważny cel teologiczny i redakcyjny. Otóż ten cykl przekazów stanowi idealne przejście od opisu życia patriarchów w Kanaanie do najważniejszych w Pięcioksięgu tradycji o pobycie i wyjściu Izraela z Egiptu, które rozpoczynają księgę Wyjścia. Tak więc budująca saga o dziejach synów Jakuba z jednej strony pełni rolę przekonywującego świadectwa o zbawczej woli Boga i Jego wierności wobec potomków Abrahama, Izaaka i Jakuba, a z drugiej wyjaśnia, w jaki sposób znaleźli się oni w Egipcie.

Jak zasygnalizowaliśmy już wyżej, historia Józefa w swej obecnej formie nie jest z pewnością jednorodną kompozycją pochodzącą od jednego autora. Porównując język, styl oraz podstawowe wątki tematyczne jej głównych komponentów, dochodzi się do wniosku, że w oryginalnej opowieści o konflikcie między synami Jakuba nie było rozdziałów Rdz 38; 48-50. Ten materiał został dołączony dopiero na późniejszym etapie literackiej krystalizacji cyklu o patriarchach. Oryginalny kształt historii Józefa $(37$; 39-47) charakteryzuje się bowiem łatwo zauważalną spójnością formy i treści. Jej wątkiem prowadzącym jest temat proroczych snów Józefa, które zostają zaprezentowane na początku relacji (37,5-11), a ich treść spełnia się stopniowo i niezawodnie w kolejnych passusach cyklu (39-47) ${ }^{9}$. Cała opowieść rozwija się więc w bardzo przejrzysty i uporządkowany sposób. Po epizodzie otwarcia, który inicjuje akcję opowiadania (konflikt Józefa z braćmi, 37,2-36), narrator w trzech kolejnych odsłonach przekonuje lektora do tego, że Bóg Jahwe nieustannie czuwa nad młodym Józefem i ratuje go z każdej opresji, w które sukcesywnie popada: najpierw z rąk

${ }^{9}$ A. Oppenheim, The Interpretation of Dreams in the Ancient Near East, Philadelphia 1956, s. 206; J. Cooper, Sargon and Joseph. Dreams Come True, w: A. Kort, S. Morschauser, Biblical and Related Studies Presented to Samuel Iwry Winona Lake 1985, s. $35 . \mathrm{Z}$ uwagi na mocno teologiczne zabarwienie i liczne powtórzenia treściowe jedynie passus 50,1426, a szczególnie wiersz 50,18 wydaje się późniejszą redakcyjną glosą pośród pierwotnych tradycji podejmujących wątek kolejno spełniających się snów Józefa. Glosa ta miała na celu mocniejsze związanie historii Józefa z tradycjami o Jakubie. G. Wenham, Genesis 16-50, s. 481-482. 
zaborczej i pożądliwej żony Potifara $(39,1-20)$, potem z więzienia $(39,21-40,23)$, a w końcu z konfrontacji z faraonem Egiptu (41,1-57). Należy też podkreślić, że na tym etapie opowiadania narrator nic nie mówi o Bożym planie zbawienia, jaki dokonuje się poprzez dzieje głównego bohatera. Do tego wniosku można dojść dopiero po lekturze całego dokumentu. Punkt kulminacyjny tej części sagi stanowi wyniesienie Józefa do godności najwyższego urzędnika w państwie.

Od tego momentu następuje stopniowe, ale coraz bardziej definitywne rozwiązywanie wszystkich problemów i konfliktów w rodzinie Jakuba, o których mowa na wstępie relacji. Rozwój akcji opowiadania wpisany jest w trójstopniową symetryczną strukturę, na którą składają się trzy kolejne wizyty członków rodu Jakuba u Józefa w Egipcie. Podczas pierwszej wizyty w kraju faraona dziesięciu synów Jakuba staje przed swym bratem i oddaje mu pokłon nie zdając sobie sprawy, że mają przed sobą ukochanego syna Jakuba (42,1-38). W ten sposób po raz pierwszy wypełniają się sny Jakuba z 39,5-10. Podobnie dzieje się podczas ich drugiej wizyty, w czasie której kłaniają się Józefowi już wszyscy jedenastu bracia. W tych dramatycznych, choć pełnych wzruszenia i emocji, okolicznościach Józef wyjawia im, kim jest $(43,1-45,28)$. Jednakże pełna realizacja otwierających narrację snów Józefa dokonuje się dopiero podczas trzeciej wizyty $(46,1-47,31)$, kiedy to przed majestatem zarządcy Egiptu pojawia się cała rodzina wraz z protoplastą Jakubem (słońce, księżyc i jedenaście gwiazd, por. 37,9-11). Przypuszczalnie tak właśnie wyglądał oryginalny kształt cyklu o Józefie. Na późniejszym etapie edycji został on opatrzony przez redaktora bądź redaktorów księgi opisem ostatnich dni Jakuba i Józefa w Egipcie $(48,1-50,26)$, który stanowi idealne podsumowanie dla obszernie opisywanej w Księdze Rodzaju historii patriarchów. W zasięgu zainteresowania tych redaktorów nie stały perypetie Józefa, lecz kolejny etap historii rodu Jakuba (Izraela), o czym można się przekonać na podstawie tytułu otwierającego tę kompozycję: "oto dzieje potomków Jakuba" $(37,2$; por. 11,27, 25,19) oraz na bazie treści innych dodatków, z których na plan pierwszy wysuwa się zdecydowanie błogosławieństwo dwunastu synów Jakuba w 49,1-28. Ten ostatni epizod stanowi jakby punkt kulminacyjny obecnej wersji historii Józefa oraz całej epoki patriarchów, ponieważ zawiera symboliczną i poetycką zapowiedź dziejów narodu, które w przyszłości rozwiną się w dwu niezależnych kierunkach, tworząc historię północnego Izraela (Efraim) i południowej Judy ${ }^{10}$. Zalążek i motyw przewodni tej historii alegorycznie ilustrują dzieje Józefa i jego braci. Cykl tradycji 37.39-47 ukazuje bowiem ostry konflikt oraz trwałe pojednanie dwunastu synów Jakuba. W tym specyficznym kontekście szczególnego znaczenia nabiera scena pojednania, która w obrębie cyklu jest powtórzona aż trzykrotnie i to z wielkim patosem. W ten bowiem sposób redaktor księgi chciał przekonać lektora, że Izrael

${ }^{10}$ R. E. Longacre, Joseph. A Story of Divine Providence, Winona Lake 1989, s. 54. 
wywodzący się od dwunastu synów Jakuba jest zdolny do trwałej zgody i ścisłej współpracy. W perspektywie całej sagi o Jakubie $(25,19-50,26)$ historia Józefa staje się zatem teologiczną dokumentacją narodzin silnego i zjednoczonego narodu Izraela, który oparty jest o strukturę dwunastu pokoleń. Tak wygląda aktualny teologiczny i ideologiczny kontekst tradycji o Józefie. Nie oddaje on jednak w pełni literackiego piękna i bogactwa poszczególnych komponentów tego cyklu. Popatrzmy zatem na omawianą sagę przez pryzmat jej oryginalnej wersji. Już bowiem pobieżnie zarysowana wyżej charakterystyka sygnalizuje jej głęboką literacką odrębność i oryginalność.

\section{TEOLOGICZNE UWARUNKOWANIA TRADYCJI O JÓZEFIE}

Wielopłaszczyznowa konfrontacja historii Józefa z tradycjami o Abrahamie, Izaaku i Jakubie ukazuje teologiczną spójność i treściową ciągłość przekazów o patriarchach, ale też nasuwa wiele wątpliwości. Z pewnością wszystkie te teksty zostały tak zredagowane, aby ukazać nieprzerwaną i obfitującą w dowody Bożej obecności prehistorię Izraela, w której głównymi bohaterami są Abraham i jego potomstwo, a jej treść wyznaczają ich życiowe perypetie od momentu wejścia do ziemi Kanaan aż do jej opuszczenia i emigracji do Egiptu. Analiza treści i kontekstu historycznoreligijnego historii o Józefie sugeruje jednakże, że w rozdziałach Rdz 37.39-47 znajdujemy się już w zupełnie innym świecie, niż to miało miejsce w przypadku relacji o Abrahamie, Izaaku czy Jakubie. Tradycje o Abramie od początku do końca obfitują w bezpośrednie ingerencje Boga. Niemalże na każdej karcie cyklu o tym pierwszym protoplaście Izraela objawia się Jahwe (15,1-21; 17,1-22; 18,1-16) i bezpośrednio z nim rozmawia $(12,1-3.7 ; 13,14-17 ; 18,22-33 ; 21,12 ; 22,1-2.11-12.15-18)$. Podobnie ma się rzecz z Izaakiem (26,2-5.24) i Jakubem (28,10-22; 32,25-33). Natomiast w zbiorze tradycji o Józefie (Rdz 37-50) Bóg zdaje się ciągle ukrywać i milczeć. W opisywane wydarzenia ingeruje bezpośrednio tylko jeden raz i to w passusie dotyczącym Jakuba $(46,1-5)$, który jest powszechnie uznawany za późniejszą teologiczną ekspansję oryginalnego cyklu o Józefie. Poza tym, w tekstach tych nikną zupełnie z pola widzenia podstawowe tematy teologiczne, które wyznaczały bieg akcji w poprzednich cyklach księgi. Chodzi tu przede wszystkim o wątek uroczystych Bożych obietnic, jakie Jahwe złożył Abrahamowi, które jak refren powracają w biblijnych tradycjach o jego potomkach: Izaaku i Jakubie (12,1-3.7; 13,14-17; 15,1-21; 17,1-22; 18,10-15; 22,16-18; 24,7; 26,2-5.24; 28,13-15; 32,25-33; 35,10-12).

Fakt, iż w przekazach o Józefie ani razu nie wspomina się o Bożej obietnicy ziemi, czy też o zapewnieniu licznego potomstwa dla kolejnych pokoleń Abrahama $^{11}$, musi zastanawiać lektora tradycji o patriarchach. Na podstawie

${ }^{11}$ Pewne aluzje do tych kwestii odnajdujemy jedynie we wspomnianej już wyżej wizji Jakuba $(46,1-5)$ oraz w pożegnalnej mowie Józefa $(50,24-25)$. Jednakże obydwa te teksty są 
lektury Rdz 37-50 można nawet przypuszczać, że Józef wcale nie odczuwał nostalgii za swym dziedzictwem w Kanaanie i nie manifestował żadnych bliższych relacji i więzi w stosunku do ziemi obiecanej ojcom. Poza tym, z chwilą gdy uzyskał stanowisko i posiadłości w Egipcie nie wykazywał żadnej inicjatywy, aby wracać do ubogiej ziemi przodków. Co więcej, gorąco zachęcał swych krewnych, by pozostawili swe dotychczasowe dobra i przenieśli się na stałe do kraju faraonów, który, według niego, nie tylko gwarantował przeżycie w latach głodu i posuchy, ale też dawał realne perspektywy na rozwój i dobrobyt. W żadnym z licznych monologów Józefa nie widać też najmniejszej aluzji ani do szczególnego Bożego wybraństwa, jakim Jahwe obdarzył Abrahama i jego potomków, ani do przywilejów, które z tego faktu wynikały. I tak, na przykład, dwaj synowie Józefa: Efraim i Manasses, wydają się pozostawać poza ścisłym obrębem potomstwa Jakuba ${ }^{12}$, a sama idea Izraela jako zjednoczonej wspólnoty pokoleń wywodzącej się od dwunastu synów Jakuba pojawia się w Rdz 37-50 niezwykle rzadko (38,11-30; 48,1-49,28).

Kolejną różnicą $\mathrm{w}$ treści i teologicznej perspektywie omawianych cyklów jest sposób, w jaki opisuje się przyczyny i konsekwencje konfliktów, jakie rodzą się wewnątrz rodziny patriarchy. Dotychczas wszelkie spory, konfrontacje i rywalizacje, które miały miejsce zarówno w najbliższej rodzinie Abrahama, jak i Izaaka, wynikały i odbywały się na tle prawa do pierworództwa i przywileju dziedziczenia. I tak, pierwszy syn Abrama narodzony z Hagar Izmael, nie mógł dłużej pozostać w domu ojca, gdyż, według Sary, był zagrożeniem dla młodszego Izaaka, który był synem obietnicy $(21,1-21)$. W kontekście tego samego prawa do dziedziczenia majątku ojca przez pierworodnego syna wybuchł ostry konflikt między potomkami Izaaka: Ezawem i Jakubem. Przedstawiona niezwykle ekspresyjnie i barwnie braterska walka o przywilej pierworództwa i wynikające $\mathrm{z}$ niego prawo do ojcowskiego i Bożego błogosławieństwa wypełnia prawie cały cykl o Izaaku i Jakubie $(25,19-35,29)$. Tego rodzaju konflikty i uwarunkowania znikają zupełnie z pola widzenia w zbiorze tradycji o Józefie. Tu źródłem konfliktu synów Jakuba nie jest uprzywilejowana pozycja najstarszego syna, czy też rywalizacja o materialne dobra ojca, lecz osobiste preferencje patriarchy, który niesprawiedliwie traktuje swych synów, ponieważ faworyzuje jedynie swych najmłodszych potomków: Józefa i Beniamina, którzy przyszli na świat z ukochanej Racheli pod koniec jego życia. Ta pełna nieuzasadnionych predylekcji postawa Jakuba manifestowana szczególnie w odniesieniu do Józefa $(37,3-4)$ stała się z czasem główną przyczyną rażącej wyniosłości i pychy mło-

teologicznymi glosami redaktora, które zostały wkomponowane w istniejące już tradycje na późniejszym etapie edycji księgi po to, aby ściślej połączyć oryginalnie niezależne przekazy o Józefie z tekstami o patriarchach.

${ }^{12}$ Por. obrzęd błogosławieństwa synów Józefa (48,1-20), który poprzedza analogiczny ryt dokonany nad synami Jakuba $(49,1-28)$. 
dzieńca (por. treść snów Józefa w 37,5-11) i spowodowała najpierw gwałtowną zazdrość pozostałych synów Jakuba, a potem ich niczym nieskrywaną nienawiść w stosunku do niepokornego brata. A zatem osnowa i kontekst zbioru tradycji o Józefie są znacząco odmienne od literackich i teologicznych uwarunkowań cyklów poprzednich. Nie chodzi już w nich o prawo do dziedziczenia ziemi obiecanej przez Jahwe, czy też o inne Boże obietnice (np. błogosławieństwo Boże objawiające swą moc w różnych sektorach codziennego życia, a szczególnie widoczne w darze licznego i silnego potomstwa), lecz o wyraźną rywalizację o pierwszeństwo, przywileje i władzę, jaka wkradła się pomiędzy dorastających synów Jakuba. Ten wątek treściowy staje się fundamentem początkowych epizodów cyklu o Józefie ${ }^{13}$, a jego nieco zmodyfikowana forma (temat rzeczywistej władzy i szerokich ekonomicznych jak też politycznych kompetencji Józefa $\mathrm{w}$ Egipcie oraz jego stosunku do braci) przewija się $\mathrm{w}$ tej czy innej postaci aż do końcowych jego passusów.

\section{ZASKAKUJĄCA „ŚWIECKOŚĆ" HISTORIl JÓZEFA}

Brak podstawowych idei teologicznych, chodzi tu głównie o kwestię przymierza i uroczystych obietnic złożonych przez Boga Abramowi, które stanowiły rdzeń wcześniejszych tradycji o patriarchach, to zasadnicza, ale nie jedyna cecha, która wyróżnia cykl o Józefie od poprzedzających go tekstów biblijnych. Uważnego lektora uderza niezwykłe, jak na biblijne teksty, otwarcie a nawet nieskrywana sympatia względem obcej judaizmowi kultury (w tym przypadku chodzi o zwyczaje egipskie), jaką manifestuje autor oryginalnej wersji relacji o Józefie. W konfrontacji z takimi tekstami, jak: Rdz 24,1-67; 25,20; 26,34-35; 27,46-30,24, w których kolejni patriarchowie baczą pilnie, aby ich synowie brali sobie za żony kobiety wywodzące się wyłącznie spośród plemion hebrajskich i aramejskich, dziwi na przykład fakt, iż Józef poślubia Asenat, córkę egipskiego kapłana Potifera z On $(41,45)$. Małżeństwo patriarchy z poganką, która ponadto jest córką kapłana służącego i oddającego cześć obcym bóstwom, zdaje się nie stanowić żadnego problemu dla redaktora tych tradycji ${ }^{14}$. Bez większych emocji

${ }^{13}$ Mówią o nim wyraźnie zarówno niezadowoleni bracia Józefa w 37,8: „masz może zamiar panować nad nami jak król i rządzić nami jak władca?”, jak i ojciec Józefa: „co miałby znaczyć ten sen? Czy ja, matka twoja i twoi bracia mielibyśmy przyjść do ciebie i oddawać ci pokłon aż do ziemi?" (37,11). W. Humphreys, Joseph and His Family. A Literary Study, Columbia 1988, s. 103nn.

${ }^{14}$ Co prawda, również w Rdz 38 (rozdział ten jest ewidentną redakcyjną interpolacją w obrębie cyklu o Józefie) informuje się o małżeństwie Judy z Kananejką o imieniu Szua $(38,2)$. Jest jednak rzeczą oczywistą, że te treści nie pochodzą z tego samego środowiska i z tej samej epoki, co chociażby wiersze 24,3;28,1, które przytaczają nakazy Abrahama i Izaaka odnośnie do związków małżeńskich ich potomków, lub też passus 26,34-35, który informuje o smutku Izaaka i Rebeki z powodu kananejskich żon Ezawa. 
biblijny narrator informuje też o tym, że Józef zupełnie przesiąkł kulturą Egiptu. Po swym społecznym awansie syn Jakuba przyjmuje od faraona nie tylko tytuł i przywileje drugiego urzędnika w kraju, ale też akceptuje zmianę swego hebrajskiego imienia na egipskie Safnat Paneach (41,37-46), co w obrębie całej narracji służy jako symboliczny znak i dowód przemiany jego osobowości. Jako najwyższy po królu dostojnik w państwie, Józef ani razu nie odwołuje się do swego naturalnego pochodzenia, czy też swej dawnej religii i zwyczajów. Przyjmuje w pełni powierzony mu urząd, a z nim również tradycje, normy i standardy pogańskiego sposobu życia. Dlatego też kolejne teksty informują lektora o tym, że Józef mówi po egipsku (używa tłumacza w rozmowie z braćmi, 42,23), ubiera się $(41,42)$ i odżywia według zwyczajów kraju, w którym żyje $(43,32)$, a także dostosowuje swą postawę do obowiązujących tradycji egipskich $(46,34)^{15}$.

O religijnej wadze i konsekwencjach tego rodzaju postawy możemy przekonać się dopiero wtedy, gdy skonfrontujemy ją na przykład z tradycjami o Danielu (Dn 1-3), Esterze i Mardocheuszu (Est 3-4) czy Machabeuszach. Wszyscy wymienieni tu bohaterowie odczuwali wielkie obawy i skrupuły w kontakcie z obcą kulturą i ze zwyczajami pogańskiego dworu królewskiego, dlatego też $\mathrm{w}$ analogicznych do Józefa sytuacjach usiłowali za wszelką cenę zachować wierność tradycjom ojców i czystość wyznawanej religii. Rezygnowali, między innymi, ze spożywania nieczystych religijnie pokarmów, a poza tym, wierni zwyczajom żydowskim, często modlili się, pokutowali i pościli (por. np. Dn 1,8-17; 6,11; 9,3-19; 10,2-3). Tego rodzaju praktyk na próżno nam szukać w cyklu tradycji o Józefie. Chociaż patriarcha w czasie pobytu w Egipcie zachowuje wiarę ojców i wyznaje jedynego Boga Jahwe (por. 40,8; 41,16.25.28.32; $45,5-9 ; 50,20)$, to jednak $w$ cyklu tradycji mu poświęconych nie ma ani jednej wzmianki o zewnętrznych praktykach religijnych typowych dla przedstawicieli jego rodu. Co więcej, z klimatu narracji można wnioskować, że Józef był bardzo szczęśliwy z zaistniałej sytuacji i swego nowego stanowiska, korzystał ze wszystkich udzielonych mu przywilejów i nie martwił się wcale o to, że taką postawą narażał się na utratę swej etnicznej odrębności i religijnej czystości. O wpływie, jaki wywarł na Józefa jego pobyt w Egipcie, może świadczyć choćby fakt, że używa egipskich a nie hebrajskich formuł przysięgi: „na życie faraona!" (42,15-16), a także, na wzór Egipcjan, praktykuje obrzęd konsultacji bóstwa (wróżby) za pomocą rytualnego pucharu (44,2.5.12.15). Prócz tego Józef bez żadnych skrupułów i wahań wychwala potęgę Egiptu, chełpi się zajmowaną przez siebie pozycją społeczną $(45,13)$ i wyraźnie zaprasza swych braci, aby po-

${ }^{15}$ Jedynym wyjątkiem od tej reguły mogą być imiona, jakie Józef nadał swym dwóm synom w Egipcie: Manasses (od hebr. mənašš ${ }^{\mathrm{h}}$ „ten, który powoduje zapomnienie") oraz Efraim (od hebr. 'ep̄rāyim „podwójny owoc", „być płodnym”) (41,51-52). Oba imiona mają znacznie wybitnie etiologiczne i manifestują wdzięczność Józefa wobec Jahwe za radykalną, trwałą i pozytywną zmianę jego losu. 
rzucili ziemię obiecaną im przez Jahwe i przenieśli się na stałe do kraju faraona. W kontekście religijnej i teologicznej opcji pozostałych cyklów o patriarchach oraz wielu innych tradycji biblijnych, ze zdziwieniem należy przyjąć również i to, że żaden z braci Józefa nie protestuje wobec tego rodzaju propozycji i nie wyraża obaw o utratę religijnej i etnicznej tożsamości w pogańskiej ziemi ${ }^{16}$. Wszyscy, wraz z patriarchą Jakubem, przenoszą się do Egiptu i osiedlają się w miejscu wskazanym im przez Józefa i faraona $(46,1-47,12)$.

Czytając uważnie kolejne epizody z pobytu Józefa i jego braci w Egipcie, odnosi się wrażenie, że narrator pragnie zarówno dokładnie opowiedzieć o tym specyficznym okresie życia patriarchy, jak też zamanifestować bardzo żywą ciekawość w stosunku do obcej kultury i zwyczajów. W kolejnych odsłonach swej kompozycji czyni to tak, jakby chciał zapoznać i zainteresować swych lektorów wielkim bogactwem i atrakcyjnością świata Egiptu. Dlatego też w historii Józefa obszernie opisuje się na przykład rozliczne funkcje egipskich dworzan i funkcjonariuszy faraona (np. kapłana Potifara, przełożonego królewskich więzień, piekarza, podczaszego, por. 39,1-40,23), przedstawia się panoramę geograficzną, społecznopolityczną, religijną i ekonomiczną Egiptu (por. np. charakterystykę ukształtowania delty Nilu i ziemi Goszen, opis administracyjnych i agrarnych struktur kraju, prezentację specyfiki i zakresu władzy faraona oraz jego nadwornych urzędników, fachową charakterystykę roli królewskich doradców, mędrców i wróżbitów, czy też sposób przekazywania władzy i inwestytury nowemu urzędnikowi, mechanizm ściągania podatków, zakres kapłańskich przywilejów itp., por. 41,1-57; 47,13-26). Poza tym oryginalna część cyklu o Józefie jest pełna obcych terminów i pojęć, spośród których najciekawszymi są imiona własne osób (Potifar, Potifera, Asenet czy Safnat Paneach, por. 39,1, 41,45), nazwy geograficzne (On, Goszen, Ramses, Abel Misraim, por. 41,45; $46,34 ; 47,11.27 ; 50,11)$, czy tytuły urzędników oraz oznaki czci i szacunku im okazywane (np. zawołanie /tytuł/ Abrek ${ }^{17}$, którym słudzy ogłaszali przejazd

${ }^{16}$ Jedyny wyłom $w$ tej tendencji opowiadania czyni tekst 46,2-4, który autoryzuje fakt porzucenia przez Jakuba ziemi obiecanej i przeniesienie się wraz z całą rodziną do Egiptu. Tekst ten jest jednak w aktualnym kontekście cyklu tradycji o Józefie późniejszą teologiczną interpolacją wzorowaną na pozostałych cyklach o patriarchach. Wskazuje na to zarówno styl (forma Bożej wyroczni objawionej we śnie patriarchy, która, nota bene, jest jedyną w całym cyklu o Józefie), jak też treść tych wierszy wyraźnie nawiązujących do Bożych obietnic deklarowanych Abrahamowi i Izaakowi.

${ }^{17}$ Egzegeci bardzo różnie tłumaczą i interpretują ten termin. Jedni uważają go za obowiązujące w Egipcie i na Bliskim Wschodzie określenie wysokiego urzędnika królewskiego. Inni widzą w tym określeniu raczej zawołanie, jakim słudzy czynili przejście w tłumie swemu przełożonemu, coś w rodzaju: „Uwaga! Wolna droga!”. Być może chodzi tu też o pojęcie wywodzące się z semickiego rdzenia brk oznaczającego prostrację, gest głębokiej rewerencji i szacunku okazywany dostojnikowi państwowemu. M. J. Dahood, Eblaite and Biblical Hebrew, CBQ 44 (1982), s. 23; J. S. Croatto, 'Abrek «Intendant» dans Gen 41,41.43, VT 16 (1966), 
Józefa ulicami miasta na królewskim rydwanie, por. 41,43). W końcu należy też wspomnieć o dokładnie opisanych obrzędach pogrzebu, jaki Józef zgotował w Egipcie swemu ojcu Jakubowi (50,2-11). Z zadziwiającą dokładnością informuje się bowiem, że ciało patriarchy zostało po śmierci zabalsamowane według zwyczajów egipskich, a sam pochówek Jakuba został dokonany z zachowaniem skomplikowanej i ściśle ustalonej procedury pogrzebowej (40 dni przeznaczone było na balsamowanie i 70 na żałobę) ${ }^{18}$, która obowiązywała w krainie faraona. Narrator nie omieszkał też zaznaczyć, że dostojność i niezwykle długi czas trwania pogrzebu wzbudził powszechny podziw i zdumienie wśród mieszkańców Kanaanu $(50,11)$. W podobny, choć znacznie skromniejszy i mniej dostojny sposób relacjonuje się też pogrzeb samego Józefa $(50,26)$.

Podsumowując wszystkie te oznaki zainteresowania obcą kulturą i tradycjami, z jakimi spotykamy się $\mathrm{w}$ Rdz 37-50, trzeba jednak stwierdzić, że informacje o Egipcie zawarte $\mathrm{w}$ biblijnych tradycjach o Józefie, choć liczne i dotyczące wielu sektorów życia społecznego i religijnego, mają charakter dość standardowy, powierzchowny i anonimowy (np. brak jest imienia egipskiego faraona, bezimienne pozostaje też miasto $(44,4.13)$, które stanowi przestrzeń dla większości toczących się zdarzeń). Te obserwacje prowadzą do wniosku, że autor cyklu o Józefie prawdopodobnie sam nigdy nie był w Egipcie, a swą znajomość tamtejszych zwyczajów i tradycji zaczerpnął z dostępnych mu źródeł. Oczywiście tego rodzaju konkluzja w najmniejszym stopniu nie podważa ogromnej sympatii i zainteresowania, jakimi darzył on kraj nad Nilem oraz panujące tam zasady i porządek.

\section{WNIKLIWA ANALIZA PSYCHIKI I EMOCJONALNEJ GŁĘBI POSTAW LUDZKICH}

Poza fascynacją pogańską kulturą Egiptu, historia Józefa zawiera wiele innych elementów, które stanowią o jej pokaźnej świeckości i odróżniają ją od wcześniejszych przekazów o patriarchach. Na pierwszym miejscy należy tu wymienić wyraźny brak religijnej i etnicznej wyłączności, z jaką spotykamy się w tekstach o Abrahamie, Izaaku i Jakubie. Na kartach oryginalnej historii Józefa, poza nielicznymi tylko wyjątkami, nie pojawiają się żadne znaczące wątki teologiczne. W Rdz 37.39-48 nie spotyka się na przykład tak zasadniczych zagadnień teologicznych jak: przymierze człowieka z Bogiem, grzech

s. 113-115; B. Redford, A Study of the Biblical Story of Joseph (VTSup 20; Leiden 1970), s. 226-228; J. Vergote, Joseph en Egypte, Louvain 1959, s. 35nn.

${ }^{18}$ C. Westermann, Genesis 37-50 (BK 1.3; NeukirchenVluyn 1982), s. 16-18; E. Lowenthal, The Joseph Narrative in Genesis, New York 1973, s. 147nn.; C. Youngblood, The Embalming Process in Ancient Egypt, Biblical Illustrator 14 (2; 1988), s. 80-83; V. P. Hamilton, The Book of Genesis. Chapters 18-50 (NICOT 2; Grand Rapids 1995), s. 691nn. 
pociągający Bożą karę, sytuacja radykalnego doświadczenia, która powoduje ufne wołanie i oczekiwanie na Boże zbawienie, konflikt woli Bożej z wolnością i niegodziwością ludzką, czy też poczucie winy, które zostaje zmazane obfitym i darmowym przebaczeniem Jahwe. W miejsce Boga i Jego wszechmocnej obecności zbawczej, która charakteryzuje zdecydowaną większość biblijnych tradycji, w Rdz 37.39-48 wchodzi świat ludzkich przeżyć i doświadczeń wraz z całym bagażem jego skomplikowanych i niejasnych uwarunkowań, planów, machinacji, emocji, dążeń i pragnień, które w mistrzowski wręcz sposób ukazuje autor cyklu o Józefie. Czytając kolejne strony historii patriarchy, odnosi się wrażenie, że mamy przed sobą profesjonalny psychologiczny elaborat, którego przedmiotem są wewnętrzne i zewnętrzne stany, akty, postawy, reakcje i sentymenty opisywanych bohaterów. Tendencja autora do psychologicznej analizy postaw głównych postaci narracji jest w niektórych fragmentach cyklu tak oczywista i znacząca, że teksty te nie znajdują sobie równych $\mathrm{w}$ tym względzie pośród wszystkich pozostałych świadectw, jakie spotykamy w Biblii.

I tak, wnikliwą analizę mechanizmów rządzących emocjami i uczuciami głównych bohaterów spotykamy w wielu miejscach narracji o Józefie. Namacalnym tego przykładem jest m.in. częstotliwość, z jaką narrator w scenie otwarcia (37,1-35) używa terminów: kochać, nienawidzić, być zazdrosnym, opłakiwać czy pocieszać. Ogromny ładunek emocjonalny opisywanej w tym rozdziale sytuacji rodzinnej ilustrują także podejmowane przez przedstawicieli rodu Jakuba działania: sprzedać, zabić, przywdziać szatę żałoby, rozedrzeć szaty itd.

Ewidentnym przykładem wielkiego kunsztu autora cyklu w analizie ludzkiej psychiki jest też passus opisujący pobyt Józefa w więzieniu $(39,20 b-$ $-40,23)$. Relacjonując spotkanie patriarchy z towarzyszami niedoli, to znaczy przełożonym piekarzy i podczaszym faraona, po raz kolejny świadomie wprowadza on lektora w świat ludzkich emocji, lęków i pragnień. Czyni to za pomocą ściśle określonej techniki narracji, dzięki której lektor za pośrednictwem Józefa dowiaduje się stopniowo o fakcie uwięzienia dwu dygnitarzy faraona (40,1-4a), o ich snach, a następnie o przyczynie ich niepewności i frasunku, którą była niemożność właściwej interpretacji doznanych wizji (40.40b-8). Lektor zostaje w ten sposób niejako przeniesiony w świat bohaterów i od wewnątrz, na równi z nimi (na równi z Józefem), poznaje pełne emocji i lęku wątki toczącej się akcji. I tak, w atmosferze rosnącego napięcia, poznajemy treść snu podczaszego dopiero wtedy, kiedy Józef deklaruje moc jego interpretacji a nie w chwili, kiedy miał on rzeczywiście miejsce. Tak samo dzieje się z treścią snu przełożonego piekarzy. Wyjawia on ją dopiero wtedy, gdy naocznie przekonuje się o tym, że Józef rzeczywiście potrafi tłumaczyć sny i gdy słyszy, że sen jego towarzysza zwiastuje pomyślne zakończenie pobytu w więzieniu. Narrator pragnie $\mathrm{w}$ ten sposób zakomunikować, że przełożony piekarzy bardzo obawiał 
się o swój los i do ostatka wahał się z objawieniem treści swego snu, sądząc, że jest on zapowiedzią nieszczęścia (40,16-19). To właśnie dlatego pozwolił, aby to jego towarzysz najpierw opowiedział swój sen. Jak pokazuje dalsza część relacji, obawy piekarza $\mathrm{w}$ pełni się potwierdziły. Nie tylko interpretacja jego snu okazała się niekorzystna, ale też niepokojący go lęk o utratę życia wkrótce stał się rzeczywistością. Na trzeci dzień został bowiem stracony przez faraona, dokładnie tak, jak zapowiedział mu Józef (40,20-22).

Relacją pełną napięcia i niezwykle trafnej analizy psychologicznego podłoża i emocji ludzkich zachowań jest również passus o zalotach żony Potifara (39,6b-20). Narrator bardzo barwnie opisuje uczuciowy proces, jaki zachodzi w sercu i umyśle Egipcjanki. Od fascynacji i pożądliwości ukierunkowanej na osobę Józefa, która w pewnym momencie przybiera formę konkretnych niemoralnych propozycji i wiąże się ze zdradą własnego męża aż po szeroki wachlarz negatywnych uczuć wynikających z faktu odrzucenia (poczucie odepchnięcia, bezsilna złość, pogarda, zazdrość, nienawiść, pragnienie zemsty, kłamstwa, fałszywe oskarżenia itd.).

Jednak najpiękniejszym przykładem głębokiej i świadomej analizy ludzkiego wnętrza są kolejne sceny relacjonujące spotkania Józefa z jego braćmi. Wystarczy wziąć pod uwagę artystyczny kunszt narratora, który za pomocą prostych, ale za to niezwykle skutecznych literackich narzędzi ${ }^{19}$, otwiera przed lektorem wnętrze umysłów i serc głównych bohaterów. Już podczas pierwszego spotkania (42,6b-24) Józef postanawia poddać swych braci próbie. Najpierw oskarża ich o szpiegostwo, a potem ich wiarygodność i prawdomówność nakazuje udowodnić przyprowadzeniem najmłodszego brata. Podczas rozmowy z Józefem jego bracia, sądząc, że egipski rządca ich nie rozumie, rozmawiał bowiem z nimi przez tłumacza, bez lęku wyjawiają swe prawdziwe i najskrytsze odczucia, a co najważniejsze, interpretują podejrzenia egipskiego urzędnika jako konsekwencję swego niegodziwego czynu popełnionego w przeszłości względem Józefa. W ten sposób narrator zapoznaje uważnego lektora nie tylko z dodatkowymi szczegółami odnoszącymi się do kluczowej sceny opowiada-

${ }^{19}$ Chodzi tu przede wszystkim o ideę tłumacza. Dzięki wprowadzeniu tego literackiego środka, autor cyklu mógł na jednej scenie wydarzeń bardzo łatwo ukazać dramat, jaki jednocześnie rozgrywał się w duszach braci oraz w sercu Józefa (42,23-24). Warto zauważyć, że na żadnym innym miejscu narracji nie powraca już motyw tłumacza. Popatrzmy więc dokładnie na skuteczność tej literackiej inwencji i zanotujmy jak ogromny ładunek emocji udało się narratorowi wyrazić w 42,21-24: „Mówili między sobą: «Ach, zawiniliśmy przeciw bratu naszemu, patrząc na jego strapienie, kiedy nas błagał o litość, a nie wysłuchaliśmy go! Dlatego przyszło na nas to nieszczęście». Ruben zaś tak im wtedy powiedział: «Czyż wam tego nie mówiłem. Nie dopuszczajcie się wykroczenia względem tego chłopca, ale nie usłuchaliście mnie. Toteż teraz żąda się odpowiedzialności za jego krew!». Nie wiedzieli zaś, że Józef to rozumie, bo rozmawiał z nimi przez tłumacza. Odszedłszy więc od nich, rozpłakał się". 
nia, czyli do faktu sprzedania Józefa przez braci ${ }^{20}$, ale też otwiera drogę do pojednania. Odtąd relacja toczy się już tylko w jednym kierunku: prowadzi do stopniowego, ale za to trwałego pojednania i przebaczenia między braćmi. Najważniejszym teologicznym orędziem całego cyklu jest bowiem przekonanie, że dwunastu potomków Jakuba stanowi jednolity i spójny fundament, na którym może powstać jeden silny naród. To dlatego narrator z jednej strony pokazuje dziesięciu braci, którzy wylewają przed sobą wielki żal i skruchę, jaka trawiła ich sumienia od chwili niechlubnego zaprzedania Józefa w niewolę, a z drugiej, paralelnie do tej dramatycznej sytuacji, ukazuje inną wzruszającą scenę, odkrywając, co dzieje się w sercu Józefa $(42,24 a)$. Szczere wyznanie winy przez braci w obecności Józefa wyzwala jego przebaczenie, litość i wzruszenie ${ }^{21}$. Otwartą i głośno manifestowaną skruchą oraz radykalną zmianą nastawienia w stosunku do nienawidzonego niegdyś Józefa, bracia budzą zrozumiałe współczucie i sympatię nie tylko jego samego, ale również i lektora. Ta wyjątkowa analiza stanu ducha głównych bohaterów zapowiada zatem rychłe pojednanie synów Jakuba i rozwiązanie podstawowego problemu narracji. Jednocześnie buduje fundament pod teologiczną strukturę aktualnej wersji cyklu (świadomie wkomponowanej w historię Jakuba /Izraela/) oraz pozostałych zbiorów tradycji o patriarchach, będących swoistą prehistorią izraelskiego narodu. Otóż wątek jedności, zgody i solidarności potomków Jakuba, który powraca jak refren w aktualnej wersji cyklu o Józefie, ma ukazać idealny obraz rodzącego się Izraela oraz stanowić teologiczne uzasadnienie jego wewnętrznej siły i niebywałego rozwoju w przyszłości (por. Wj 1,1-7).

Najważniejszą dla rozwoju akcji analizą wewnętrznych postaw głównych bohaterów cyklu Rdz 37-50 jest jednak scena, która opowiada o próbie, jakiej Józef poddał swoich braci w 44,1-45,15. W wyniku tej próby zostały rozwiązane wszystkie główne konflikty i napięcia ukazane w dotychczasowej relacji. Z jednej strony ukazany jest w tym passusie misterny plan Józefa, który pragnie ostatecznie przekonać się co do prawdziwych intencji swych braci i co do szcze-

${ }^{20}$ Wiersze 37,23-28 w najmniejszym stopniu nie informowały o reakcji Józefa na zamach dokonany na jego osobę ze strony braci, natomiast z wiersza 42,21 można wywnioskować, że błagał on usilnie o litość. Analizując duchowy stan braci Józefa, można by przypuszczać, że dopiero teraz, kiedy poczucie winy stało się na tyle mocne, iż zaczęło doskwierać w ich sercach, są w stanie usłyszeć wołanie brata. Trzynaście lat wcześniej, kiedy ich umysły i serca były zaślepione pragnieniem zemsty, gniewem i nienawiścią do Józefa, byli głusi na błagania swego młodszego brata.

${ }^{21}$ Największy ładunek emocjonalny zawiera w sobie kolejna scena spotkania Józefa z braćmi, podczas której objawia on swą prawdziwą tożsamość oraz głośno przebacza braciom ich postępek. Tym razem powodem wzruszenia i wielkich emocji Józefa, co dokładnie i w pełen literackiego kunsztu sposób ukazuje narrator w 43,29-30, jest widok najmłodszego z braci - Beniamina. S. Schimmel, Joseph and His Brothers. A Paradigm for Repentance, Judaism 37 (1988), s. 60-65. 
rości nieświadomie i spontanicznie okazanej wobec niego skruchy (42,21-23). Dlatego też w podróżnej torbie Beniamina najpierw kazał ukryć swój kielich, by mieć motyw dla oskarżenia braci, a potem, w obliczu niekwestionowanej winy Beniamina, Józef postanawia zatrzymać go jako niewolnika. W rzeczywistości jednak pragnie poddać swych braci trudnej próbie, aby przez to wybadać ich rzeczywisty stosunek do faworyzowanego przez ojca najmłodszego syna. Znając doskonale stosunki panujące w domu Jakuba (miłość do Racheli i zrodzonych z niej synów) oraz okoliczności, w jakich sam stał się przedmiotem odrazy braci (por. 37,1-36), postanawia więc powtórzyć tę sytuację. To już trzeci raz, kiedy to narrator stawia lektora wobec analogicznych okoliczności. Pierwszy raz miało to miejsce $\mathrm{w}$ chwili, kiedy Józef stanął sam jeden wobec nienawidzących go i pragnących zemsty braci $(37,18-36)$. Po raz drugi paralelna sytuacja powtórzyła się podczas pierwszej wizyty braci w Egipcie, kiedy to oskarżeni o szpiegostwo bez żadnych protestów zostawili jednego spośród siebie (Symeona) w Egipcie, a sami, zadowoleni, że uratowali życie, wrócili do domu ojca, nie przejmując się losem brata $(42,24)$. Teraz $(44,1-45,15)$ jednak akcja zdarzeń toczy się już w zdecydowanie odmienny sposób. Po pierwsze, należy zauważyć daleko posuniętą analogię między faktami opisywanymi w 37,1-36 a 44,1-34. Beniamin występuje tu jako nowy Józef, gdyż on również jest umiłowanym synem Jakuba. Kiedy bracia poszli pierwszy raz do Egiptu on jeden pozostał przy ojcu, tak jak to było w młodości Józefa (37,12-14; 42,1nn). Czyniąc Beniamina swym niewolnikiem, Józef daje więc braciom doskonałą okazję, aby odegrali się na faworyzowanym przez Jakuba najmłodszym bracie, tak jak to uczynili w przeszłości w stosunku do niego. Podstawowym więc wątkiem tych wierszy jest odpowiedź na pytanie o rzeczywistą przemianę w sercach potomków Jakuba i o ich solidarność i odpowiedzialność za siebie, którą mocno nadszarpnęła historia z Józefem.

Tej odpowiedzi udziela nam nadzwyczaj długi monolog Judy², w którym za pomocą niezwykle barwnej historii o pełnym smutku i cierpienia życiu Jaku$b^{23}$ próbuje przekonać egipskiego rządcę o odstąpieniu od powziętego zamiaru. Według Judy, Jakub nie przeżyłby wieści o utracie Beniamina. Jednakże na Józefie, a zarazem również na lektorze tych tekstów, największe wrażenie robi nie ta barwna opowieść, ale podsumowująca ją decyzja Judy, który z miłości do ojca i z powodu złożonej wobec niego przysięgi $(43,8-10)$ ofiaruje się, aby zostać w Egipcie w miejsce Beniamina. Ten passus to literacka perła, która lśni

${ }^{22}$ Warto zauważyć, że jest to objętościowo najdłuższa wypowiedź jednego bohatera (monolog), jaką spotykamy nie tylko w zbiorze tradycji o Józefie, ale w całej księdze Rodzaju.

${ }^{23} \mathrm{~W}$ wywołujący bardzo silne wzruszenie i emocje sposób Juda opowiada egipskiemu dostojnikowi o tragicznych wydarzeniach, które w przeszłości zmąciły pokój w sercu i w domu swego ojca Jakuba: o ogromnej miłość do Racheli i narodzonych z niej synów: Józefa i Jakuba, o śmierci jednego z nich oraz o cierpieniu, jakie spowodowałaby w sercu starego ojca utrata kolejnego umiłowanego syna (44,18-34). 
blaskiem retorycznej finezji oraz kompetencją autora w kwestii psychologicznej analizy postaw ludzkich. Pokazuje on wyraźnie proces wewnętrznej przemiany braci w stosunku do ojca oraz jego umiłowanych synów. Partykularyzm i uczuciowe preferencje Jakuba, które w przeszłości spowodowały zazdrość, nienawiść i żądzę zemsty dziesięciu braci w stosunku do Józefa, kilkanaście lat później owocują już radykalnie odmienną postawą. Bracia szanują wybór ojca. W ich sercach zwycięża wspaniałomyślność, hojność i solidarność, dlatego też w chwili, w której mogliby kolejny raz pozbyć się faworyzowanego przez starego ojca brata, biorą go w obronę. Jak przystało na przedstawicieli jednego i ściśle zjednoczonego rodu, starszy brat ${ }^{24}$ bierze na siebie odpowiedzialność za czyny młodszego i niedoświadczonego Beniamina. Z miłości do domu ojca jest gotowy zrezygnować z przysługujących mu na mocy starszeństwa przywilejów, a nawet zostać niewolnikiem. Ten passus staje się momentem przełomu w całym cyklu, powoduje głębokie wzruszenie w Józefie oraz przejmującą scenę pojednania dwunastu braci (45,1-15), która jest długo oczekiwanym rozwiązaniem konfliktu zaistniałego na początku opowiadania.

Swój artystyczny kunszt i całkowitą kontrolę nad formą opisywania zdarzeń autor tych tekstów potwierdza również w scenie, która podsumowuje historię Józefa i opowiada o jego spotkaniu z ojcem $(46,29-34)$. W kontekście bardzo rozbudowanych oraz bogatych w uczucia i emocje dotychczasowych relacji należałoby się spodziewać, że opis tak długo oczekiwanej sceny powitania starego ojca z uznawanym przez lata za nieżyjącego umiłowanym synem Józefem będzie bardzo podniosła, obfitująca w silne emocje i wzruszenie, gorące słowa i rozpamiętywanie minionych zdarzeń. A tymczasem nieoczekiwanie lektor napotyka jedynie na skromną informację o przybyciu Jakuba do egipskiej ziemi Goszen i o krótkiej, chociaż niewątpliwie radosnej i wzruszającej scenie powitania Jakuba z Józefem (46,29b). Jedyną ilustracją tego, zdawać by się mogło, bardzo istotnego faktu jest krótka sentencja starego ojca: „teraz mogę już umrzeć, skoro zobaczyłem ciebie, że jeszcze żyjesz" (49,30b). I na tym koniec. Widać więc wyraźnie, że w narracyjnej strategii autora cyklu najważniejsze miejsce zajmuje scena pojednania Józefa z braćmi. Dlatego też passus relacjonujący przybycie Jakuba do Egiptu jest interpretowany już tylko jako naturalna konsekwencja tamtego wydarzenia.

${ }^{24}$ Nieskazitelna postawa Judy i najbardziej uprzywilejowane miejsce, jakie przydziela się mu w obrębie cyklu (por. 37,26-27; 43,310; 44,18-34; 46,28, a szczególnie 49,8-12) jest prawdopodobnie owocem późniejszych redakcyjnych elaboracji oryginalnego tekstu cyklu o Józefie, którego dokonano w Królestwie Południowym. A. Caquot, La parole sur Juda dans le testament lyrique de Jacob (Gen 49,8-12), Sem 26 (1976), s. 5-32; H. Seebass, Die Stämmesprüche Gen 49,3-27, ZAW 96 (1984), s. 333-350. 


\section{POEMAT O MĄDREJ, ROZTROPNEJ I SŁUŻEBNEJ WŁADZY}

O literackim nowatorstwie i specyfice historii Józefa świadczy nie tylko niezwykle żywe, jak na tradycje biblijne, zainteresowanie światem ludzkiej psychiki, uczuć i emocji. W centrum uwagi autora Rdz 37.39-47 znajduje się też inna bardzo ważna kwestia dotycząca człowieczej egzystencji, a mianowicie temat władzy sprawowanej na różnych płaszczyznach życia. Poza tym, dużą wagę przykłada się też do życiowej mądrości, roztropności, zaradności, a nawet przebiegłości, które zazwyczaj decydują o pomyślnym skutku wszelkiego rodzaju podejmowanych inicjatyw i pozwalają na wyjście z różnych prób i doświadczeń. Czytając kolejne karty historii Józefa, można dojść do wniosku, że jednym $z$ jego tematów wiodących jest wątek rządzenia i panowania, i to zarówno w swym pozytywnym, jak i negatywnym wymiarze. Od samego początku relacji problem ten pojawia się $\mathrm{w}$ różnej formie i w różnym natężeniu. Wszystko rozpoczyna się od konfliktu Józefa z braćmi, którego podłożem jest właśnie władza i przywództwo. Narrator mówi o tym bezpośrednio, gdy opisuje reakcje braci na sny Józefa w 37,8. Chociaż starsi bracia Józefa, jak się okaże w dalszej części narracji, właściwie interpretują wizje młodzieńca, to jednak na tym etapie opowiadania radykalnie sprzeciwiają się ich treści, pytając Józefa z niedowierzaniem, oburzeniem a nawet z nienawiścią: „czyż miałbyś jako król panować nad nami i rządzić nami jak władca?" $(37,8 \mathrm{a})^{25}$. Podobnie reaguje też jego ojciec, Jakub: „czyż ja, matka twoja i twoi bracia mielibyśmy przyjść do ciebie i oddać ci pokłon aż do ziemi?" (37,10b). Wprawdzie w jego wypowiedzi nie pojawia się bezpośrednio termin, który sugeruje sprawowanie królewskiej władzy przez Józefa, ale gest prostracji, o którym wspomina Jakub, odwołując się do treści snu syna, jednoznacznie wskazuje na podobny zakres tematyczny tego wiersza. W tekstach biblijnych czasownik šāhăh, wyrażający głęboki gest uniżenia, szacunku i prostracji wobec Boga, ma często również wyraźne konotacje polityczne i oznacza postawę posłuszeństwa i rewerencji wobec króla lub politycznego zwierzchnika, która manifestuje i uznaje jego wyższość i władzę $e^{26}$. W konkretnym przypadku Rdz 37, zarówno ojciec jak i bracia Józefa interpretują treść jego snów jako zapowiedź ich poddaństwa, chociaż traktują ją jako

${ }^{25}$ Terminologia użyta $\mathrm{w}$ tym wierszu bardzo ściśle odnosi się do rzeczywiście sprawowanej władzy. W 37,8 są użyte dwa hebrajskie pojęcia: mālak "sprawować władzę królewską, być królem, panować jako król” oraz māšal „dzierżyć władzę, panować, dominować nad kimś lub nad czymś".

${ }^{26}$ Niektórzy egzegeci do nurtu terminologii podejmującej temat władzy i panowania zaliczają również informację o stroju Józefa (tunika z długimi [ozdobnymi] rękawami w wierszu 37,3), który identyfikują ze strojem królewskim (por. 2 Sm 13,18). J. L. Ska, La scoperta del disegno di Dio nella storia di Giuseppe, Studio Biblico Teologico Aquilano 13 (1994), s. 123; V. P. Hamilton, The Book of Genesis, s. 407-409. 
wyraz wybujałej pychy i zarozumialstwa rozkapryszonego przez własnego ojca młodzieńca i radykalnie się jej sprzeciwiają.

Ta scena, jak sygnalizowaliśmy wyżej, jest kluczową dla dalszego przebiegu akcji opowiadania i wokół niej rozegra się główny wątek narracji. Pomimo gwałtownego sprzeciwu zamanifestowanego w passusie otwarcia $(37,8)$, bracia nie tylko raz, ale kilkakrotnie upadną przed Józefem i oddadzą mu głęboki pokłon z twarzą zwróconą aż do ziemi. W sposób nieświadomy uczynią to zarówno podczas swej pierwszej, jak i drugiej wędrówki do Egiptu, kiedy przybędą tam w celu zakupu żywności dla domu swego ojca $(42,6 ; 43,26.28)$. Uczynią to również w chwili dramatycznego powrotu do posiadłości egipskiego dostojnika, kiedy to w podróżnej torbie Beniamina odnaleziony zostanie kielich Józefa $(44,14)$. Ale ten sam gest prostracji i głębokiego uniżenia, który ze swej natury składany jest tylko przed tym, od kogo zależy życie albo śmierć, powtórzą też w stosunku do Józefa zupełnie świadomie. Dzieje się tak po śmierci i pogrzebie Jakuba, kiedy bracia w obawie przed zemstą Józefa będą gotowi poddać się władzy swego młodszego brata, a nawet stać się jego niewolnikami $(50,18)$. Ta ostatnia scena ma szczególne znaczenie dla rozwoju akcji opowiadania, gdyż synowie Jakuba kłaniają się w geście głębokiego posłuszeństwa i uniżenia już nie egipskiemu dostojnikowi, od którego zależało ich życie w kontekście plagi głodu, ale przed swym własnym bratem, którego obawiają się z powodu wyrządzonej mu uprzednio krzywdy. W tym właśnie miejscu realizuje się jeden z głównych tematycznych wątków całego cyklu: spełniają się definitywnie i dosłownie sny Józefa.

Kwestia władzy i panowania nie ogranicza się jednak tylko do relacji Józefa w stosunku do jego braci. Bardzo szeroko argument ten zostaje potraktowany również $\mathrm{w}$ tych partiach cyklu, które mówią o politycznym awansie Józefa oraz o sposobie sprawowanych przez niego rządów. Po pierwsze, narrator bardzo wyraźnie informuje lektora, a następnie wielokrotnie mu przypomina, że Józef został wyniesiony do najwyższej władzy w państwie i w zakresie swego panowania ustępuje jedynie faraonowi $(41,37-44 ; 45,9.26 ; 47,6)$. Z tekstu biblijnego wynika, że tak właściwie to cały Egipt był poddany jego rozkazom i z woli faraona pełnił niczym nieograniczoną władzę. Swój społeczny awans Józef, według oryginalnej wersji cyklu, zawdzięcza nadzwyczajnej inteligencji i niecodziennej umiejętności interpretowania snów, której nie mogli się równać najbardziej światli mędrcy i wróżbici faraona (41,8-38). W oparciu o te zdolności, jak też niekwestionowane wsparcie własnego Boga (39,2-6; 21-23; 40,8; 41,16.38-39), Józef potrafił wyjść nie tylko z kolejnych opresji i dramatycznych doświadczeń, ale też odpowiednio zaradzić potrzebom innych ${ }^{27}$. Wpierw kie-

${ }^{27}$ W kontekście całego cyklu wygórowane mniemanie o sobie, jakie Józef prezentuje w scenie otwarcia w stosunku do swych braci i rodziców $(37,2-11)$, wydaje się w pełni uza- 
rował majątkiem Potifara, dowódcy przybocznej straży faraona $(39,1-6)$, potem więzieniem, do którego został niesprawiedliwie wtrącony $(39,20 \mathrm{~b}-23)$, a z kolei całym Egiptem (41,37-44; 47,13-26). W rozsądny, kompetentny i przekonywujący sposób najpierw podpowiedział faraonowi sposób zaradzenia zbliżającej się plagi głodu, a potem umiejętnie i przemyślanie zrealizował swą wizję ocalenia kraju (41,33-36; 47,13-26). Projekt Józefa, który być może odzwierciedla rzeczywisty system podatkowy na Bliskim Wschodzie, jest niczym innym jak zaplanowanym schematem przymusowych kontrybucji nałożonych na obywateli Egiptu na rzecz państwa (jedna piąta zbiorów), które były skrupulatnie magazynowane w spichlerzach królewskich i stanowity rezerwę na czas posuchy. Plan działania Józefa zakładał po prostu konsekwentne egzekwowanie należnej królowi części zbiorów w czasach urodzaju oraz ich gospodarne dysponowanie w okresie głodu. W ten sposób można było przezwyciężyć nawet długotrwały okres nieurodzaju.

Wyraźnie określone i dość uciążliwe systemy podatkowe były powszechnie stosowane od zarania struktur monarchii na Bliskim Wschodzie, gdyż były potrzebne, aby utrzymać stale rozwijające się struktury państwowe (por. 1 Sm 8,11-18). Oczywiście propaganda królewska głosiła, że tego rodzaju przedsięwzięcia były niezbędne i niezwykle użyteczne, gdyż służyły całemu narodowi. Te obowiązujące wówczas normy i zwyczaje zostały wykorzystane w celach ideowych również w cyklu tradycji o Józefie. Narrator włożył je w usta patriarchy jako dowód jego mądrości, zaradności i Bożej asystencji, a ponadto ukazał jako jedyny plan, który mógł zażegnać zagrażający Egiptowi kataklizm. Poza tym mamy tu do czynienia z idealną koncepcją władcy. Narrator przedstawia bowiem Józefa nie tylko jako doskonałego rządcę, który potrafi zaradzić nawet niebezpieczeństwu, które zagraża całemu narodowi, ale jako idealnego przywódcę, którego głównym motywem działania jest dobro powierzonego sobie ludu (41,36b). Te same cechy Józefa autor cyklu podkreśla również w opisie jego relacji do rodzonych braci. W chwili ich przybycia do Egiptu, Józef mógłby wykorzystać swoją pozycję polityczną i społeczną do tego, aby zemścić się i przykładnie ukarać swych surowych braci za doznane za ich przyczyną upokorzenia i zniewagi. Jednakże on, jak na idealnego przywódcę i rządcę przystało, nie kieruje się doraźnymi i osobistymi korzyściami czy pobudkami, lecz ma na względzie jedynie ich dobro. Pomaga im przetrwać czas głodu i poddaje ich próbie, aby wykształcić $\mathrm{w}$ nich ducha odpowiedzialności i solidarności $(42,1-45,15)$. Ta jego pełna szlachetności i wspaniałomyślności postawa wobec winowajców nie jest ani wyrachowana, ani obliczona na doraźne przywileje, jak to często bywa w przypadku ludzi władzy i polityki, ale jest podyktowana

sadnione. Okazuje się bowiem młodzieńcem niezmiernie utalentowanym, mądrym i przedsiębiorczym. 
dojrzałą bratnią miłością oraz bojaźnią Bożą. Dowodem tego jest scena, jaka rozegrała się po śmierci Jakuba. Po pogrzebie ojca, bracia Józefa wpadli po raz kolejny w przerażenie, sądząc, że łaskawość skrzywdzonego i upokorzonego przez nich krewnego zakończy się wraz z życiem ich ojca. Przyzwyczajeni do obowiązujących w kręgach władzy standardów, postanawiają więc uprzedzić fakty i sami deklarują się niewolnikami potężnego urzędnika egipskiego. Wymownym gestem prostracji $(50,17)$ potwierdzają swoją uległość i zapowiadają ślepe posłuszeństwo, uznając tym samym społeczną i polityczną władzę swego brata. Odpowiedzią na ten akt uniżenia jest niezwykle barwna i wyidealizowana reakcja Józefa, którego narrator znowu przedstawia jako wzorcowego rządcę i przywódcę, który boi się Boga i dla którego najważniejszym celem i motywem działania jest służba na rzecz potrzebujących: „Nie bójcie się! Czyż ja jestem na miejscu Boga? Wy niegdyś knuliście zło przeciwko mnie, Bóg jednak zamierzył to jako dobro, żeby sprawić to, co jest dzisiaj, że przeżył wielki naród. Teraz więc nie bójcie się, będę żywił was i dzieci wasze" (50,19b-21a).

Oczywiście ten tekst nosi na sobie ślady teologicznej elaboracji podkreślającej biblijną koncepcję władzy i panowania, według której jedynie sam Bóg jest królem Izraela i może sprawować rządy nad potomkami Jakuba. Takiej władzy nie może sobie uzurpować żaden człowiek, to znaczy ani monarcha (por. Wj 3-15; 1 Sm 8-12), ani jakikolwiek inny urzędnik czy dostojnik. Pozytywnym przykładem tej biblijnej formy władzy jest właśnie Józef, który w 50,18-21 natychmiast odrzuca od siebie możliwość podporządkowania sobie braci i daje jednocześnie teologiczne uzasadnienie swojej decyzji: posiadając wielką i realną władzę w państwie, ciągle pozostaje tylko człowiekiem i nie może uzurpować sobie Bożego prawa do decydowania o życiu innych ludzi. Tylko Bóg ma prawo, by odbierać cześć i szacunek w sposób, w jaki chcieli uhonorować go bracia. Mimo uprzywilejowanej pozycji społecznej zajmowanej w Egipcie, Józef ciągle pozostaje członkiem swej rodziny i nie może, według narratora, zajmować miejsca, które czyniłoby go wyższym od pozostałych braci ${ }^{28}$. Solidarna miłość do przedstawicieli swego rodu chroni zatem Józefa od nieuporządkowanej pokusy władzy i posiadania. W ten sposób staje się wzorcem biblijnego rządcy, który wykorzystuje swe wpływy i świecki autorytet tylko do tego, aby pomóc wszystkim potrzebującym: domowi ojca, narodowi Egiptu i innym ludom ${ }^{29}$. Pierwszym bowiem zadaniem władzy jest ochrona najsłabszych i ratunek powierzonej sobie społeczności w chwilach zagrożenia i klęski.

${ }^{28}$ Wiersze te pozostają $\mathrm{w}$ otwartym konflikcie do treści sceny otwierającej cykl tradycji Rdz 37-50 (chodzi tu szczególnie o tekst 37,1-32), w której królowała zazdrość i nienawiść pomiędzy Józefem a jego starszymi braćmi. Te bardzo negatywne odczucia zostały wywołane wygórowanymi ambicjami oraz poczuciem wyższości Józefa.

${ }^{29} \mathrm{Z}$ podobną idealną koncepcją władcy spotykamy się wielokrotnie $\mathrm{w}$ innych tekstach biblijnych: 2 Sm 22,1-51; 23,1-7; 1 Krl 3,1-5,14; Est 4-8; Ps 45; 72. 
Kolejną cechą cyklu o Józefie świadczącą o jego literackiej specyfice i odróżniająca go od pozostałych zbiorów tradycji o patriarchach jest niezwykle mocny nacisk, z jakim podkreśla się mądrość i inteligencję głównego bohatera oraz jego stałą i wypróbowaną umiejętność kierowania własnym życiem nawet $\mathrm{w}$ najtrudniejszych doświadczeniach. W oryginalnym korpusie tego zbioru przekazów Józef jest prezentowany przede wszystkim jako kompetentny rządca, ale też jako człowiek rozsądny, mądry i roztropny (41,33.39), na którym stale spoczywa duch Boży $(41,38)$. Do takiego wniosku dochodzą kolejne postacie narracji: Potifar $(39,2-6)$, zarządca więzienia $(39,21-23)$, przełożony podczaszych faraona $(41,9-13)$ oraz dostojnicy i cały lud Egiptu $(47,13-26)$. Co warte podkreślenia, najmocniej tę pochlebną opinię o Józefie wyraża sam faraon $(41,37-45)$ i potwierdza ją wręcz nieprawdopodobnym zaufaniem. Zafascynowany naturalnymi predyspozycjami Józefa, jego inteligencją, mądrością i przenikliwością, decyduje, aby władzę w całym kraju oddać w ręce cudzoziemca, który nie tylko trafnie zinterpretował jego tajemnicze sny, ale też przedstawił konkretny sposób zażegnania niebezpieczeństwa, jakie groziło Egiptowi. Niedawny więzień wykazał się przez to wiedzą, która przewyższała możliwości wszystkich doradców i wróżbitów królewskich. Te przymioty Józefa $^{30}$ przesądziły o jego natychmiastowym wywyższeniu i awansie społecznym, a w dalszej perspektywie cyklu okazały się decydujące o kolejach losu rodu Jakuba oraz o przetrwaniu całego Egiptu i okolicznych ludów. Mądrość, inteligencja, zaradność, posiadanie Bożego ducha były bowiem cechami, jakich wymagano od rządców, królów i wszelkich innych decydentów nie tylko w świecie Biblii, ale też na całym Bliskim Wschodzie ${ }^{31}$. Na potwierdzenie tej tezy wystarczy przywołać postulat, jaki postawiony został w chwili wyboru sędziów, którzy mieli stanąć u boku Mojżesza, aby pomóc mu w zarządzaniu ludem. Tekst Pwt 1,13-15 mówi wyraźnie, że mają oni być rozumni, mądrzy i powszechnie szanowani. Podobne orędzie proklamuje również passus relacjonujący sen Salomona w Gibeonie, który inauguruje jego panowanie w Izraelu i zapowiada szereg przedsięwzięć, które z literackiego i ideologicznego punktu widzenia były konsekwencją daru mądrości (,,serce pełne rozsądku do sądzenia

${ }^{30}$ Wskutek teologicznej elaboracji oryginalnego tekstu o Józefie, niektóre jego passusy w sposób nienaturalny dla jego ogólnej koncepcji literackiej mocno akcentują ingerencję Boga w opisywane wydarzenia. W świetle tej teologicznej (dołączonej) interpretacji, to Bóg Jahwe nieustannie sprawiał, że wszystko, co czynił i przedsiębrał Józef, kończyło się powodzeniem $(39,2-5.21-23)$.

${ }^{31}$ Wystarczy przestudiować archiwalne dokumenty akkadyjskie, neoasyryjskie, ugaryckie, fenickie, aramejskie, egipskie, sumeryckie, aby odkryć bliski związek semantycznego rdzenia «być mądrym» z tytułami i funkcjami najważniejszych urzędów w państwie (król, książę, rządca, dostojnik królewski). M. Krause, H. P. Müller, șhḳham, w: G. Botterweck, H. Ringgren, Theological Dictionary of the Old Testament, t. IV, Grand Rapids 1997, s. 364-385. 
ludu i rozróżniania dobra od zła"), jakiego Bóg udzielił synowi Dawida (1 Krl 3,4,-15; 3,16-10,29) 32 .

Mądrość i inteligencja, akcentowane z taką wyrazistością w cyklu o Józefie, należą do najjaśniejszych wątków tej narracji, przez co stawiają patriarchę w kręgu najwybitniejszych postaci Starego Testamentu i czynią z niego biblijny wzorzec królewskiego rządcy i doradcy. Ale to wcale nie ten aspekt opisywanej w Rdz 37.39-47 rzeczywistości jest najważniejszy. Najistotniejszym dla narratora wydaje się fakt, iż mądrość Józefa ma zupełnie inne źródło niż ta, którą reprezentuje faraon i jego egipscy dostojnicy i mędrcy. O jej genezie aż dwukrotnie wypowiada się sam główny bohater cyklu, kiedy wyjaśnia swym rozmówcom (dostojnikom królewskim w 40,8 oraz faraonowi w 41,16), skąd posiada zdolność właściwej interpretacji snów. Nie jest ona owocem studiów czy ludzkich wysiłków, lecz wyłącznym darem Boga. Wiedza, mądrość, przenikliwość i roztropność, którymi Józef znacznie przewyższa zdolności najwybitniejszych ludzi Egiptu (41,8-36), pochodzi bezpośrednio od Boga, dlatego też nie może się z nią równać żadna zdolność ludzka. Historia Józefa, choć nie kryje swego podziwu i szacunku wobec kultury i wiedzy Egiptu, to jednak równocześnie stwierdza z satysfakcja, że nie może ona konkurować z mądrością Bożą, którą Jahwe objawia przez wybranych przez siebie potomków Jakuba, a więc protoplastów narodu izraelskiego. Cykl o Józefie, podobnie jak analogiczna w tym względzie część księgi Daniela (por. Dn 1,1-6,29, a szczególnie teksty 4,16-24; 5,13-30), ma zatem w ostatecznym rozrachunku wymowę tekstu naznaczanego wyraźnymi rysami ideowymi i propagandowymi, który ma podkreślić wyższość tradycji i religii żydowskiej nad innymi kulturami Bliskiego Wschodu ${ }^{33}$. Z jednej strony narrator przyznaje, że kulturowe, społeczne, gospodarcze i polityczne zdobycze Egiptu w wielu dziedzinach przewyższają osiągnięcia społeczności Izraela, ale z drugiej mocno podkreśla, że i tak są one podrzędne w stosunku do prawdziwej mądrości, która należy do Boga i z Jego woli stała się udziałem jednego z synów Jakuba (Izraela). Na podstawie historii Józefa lektor dochodzi bowiem do przekonania, że Egipt został ocalony nie przez sławnych mędrców i królewskich doradców faraona, którzy reprezentowali potęgę i tradycje wielowiekowego imperium, lecz przez obdarowanego Bożym duchem i mądrością

${ }^{32}$ Można tu przytoczyć jeszcze szereg innych tekstów z ksiąg dydaktycznych i prorockich, które oczekując na idealnego monarchę Izraela, na którym spocznie duch Pański, duch mądrości i rozumu (Iz 11,2), sławią wszystkich mądrych władców, a roztropność, inteligencję oraz umiejętność sądzenia i zarządzania zaliczają do najważniejszych przymiotów króla (Prz 1,1nn; 25,1nn; Koh 1,12nn; Mdr 6,1nn; Syr 10,1-5).

${ }^{33}$ To ogólne teologiczne orędzie, wskazujące wyraźnie na nadprzyrodzone źródło inteligencji Józefa, mocno modyfikuje oryginalny (świecki) charakter przekazu, a poza tym równoważy widoczny $\mathrm{w}$ wielu miejscach cyklu nieskrywany zachwyt i sympatię narratora względem kultury Egiptu. 
Józefa. Groteski i ironii tej sytuacji rozmyślnie przydaje jeszcze fakt, iż Józef był tylko niewykształconym pasterzem trzód (46,31-34), którymi wprost pogardzali Egipcjanie, a ponadto, wywodził się z nikomu nieznanego rodu, był cudzoziemcem, niewolnikiem, a na dodatek więźniem. Jednym słowem, z pewnością nikt w Egipcie nie szukałby ratunku czy rady u kogoś takiego jak Józef. A jednak Bóg, obdarzając go przewyższającą wszystkich mądrością i przenikliwością umysłu, uratował okoliczne ludy i społeczności, a jednocześnie upokorzył wielkość faraona i Egiptu. Oto jeden z kliku ukrytych w historii Józefa teologicznych wątków, które w oparciu o przeprowadzoną dotąd analizę literacką i egzegetyczną postaramy się wydobyć na koniec naszych poszukiwań.

\section{NIEZMIERZONA MĄDROŚĆ BOŻEGO PLANU ZBAWIENIA WOBEC RODU JAKUBA I EGIPTU}

Główną narracyjną osnową cyklu tradycji o Józefie są zawiłe perypetie życiowe patriarchy wyznaczone kolejnymi radykalnymi zwrotami w biegu zdarzeń, które następują zazwyczaj wtedy, gdy udaje mu się już zdobyć względnie trwałą egzystencjalną stabilizację. I tak, uprzywilejowana pozycja w domu ojca doprowadza go do ostrego konfliktu z braćmi i kończy się pierwszą gwałtowną przemianą $\mathrm{w}$ życiu. Józef traci wszystkie dotychczasowe przywileje, a na dodatek staje się niewolnikiem i sługą wędrownych kupców, a następnie egipskiego urzędnika. Kiedy dzięki wrodzonej inteligencji i zaradności udaje mu się odnaleźć wyjście z tej trudnej sytuacji (zyskuje zaufanie swego mocodawcy i zarządza całym jego majątkiem), popada $\mathrm{w}$ nowe tarapaty. Wpada $\mathrm{w}$ oko zaborczej żony Potifara, a jej żądza i urażona ambicja wtrąca go wkrótce do więzienia. Kolejny więc raz traci uprzywilejowaną pozycję i musi borykać się z nędzą i upokorzeniem. Ale wkrótce, znów dzięki niespotykanej umiejętności zyskiwania zaufania, zdobywa przychylność przełożonego więzienia i awansuje w hierarchii więziennej, tak iż zostaje więziennym zarządcą ${ }^{34}$. Wydaje się więc, że losy głównego bohatera narracji ponownie się stabilizują. Jednak i ta sytuacja trwa tylko przez chwilę. Po przekonywującej, a co najważniejsze, prawdziwej i niezwykle trafnej interpretacji symbolicznych snów współwięźniów i jej natychmiastowej realizacji, narrator sugeruje, że wkrótce znów nastąpi pomyślny zwrot $\mathrm{w}$ życiu Józefa. I choć nie następuje on natychmiast, podczaszy faraona zapomina bowiem na jakiś czas o Józefie, to jednak niedługo staje się on faktem. Józef jako jedyny z otoczenia faraona tłumaczy jego wizje oraz podaje przekonywujący plan rozwiązania kryzysu, jaki grozi Egiptowi. W odpowiedzi

\footnotetext{
${ }^{34}$ Osobiste zalety głównego bohatera cyklu oraz jego powołanie i predyspozycje do zarządzania innymi i sprawowania władzy, to jeden z bardzo istotnych wątków tematycznych przewijający się jak refren praz całą kompozycję.
} 
na jego niezwykłą wiedzę i zdolności faraon mianuje go najwyższym urzędnikiem w państwie, tak więc kolejny raz życie Józefa radykalnie się zmienia. Tym razem przemiana ma już wymiar bardziej stabilny. Józef utrzymuje swą społeczną pozycję i zdobyte przywileje aż do końca swego życia.

Jednakże treść pierwszych scen cyklu (konflikt Józefa z braćmi) domaga się jeszcze jednej, najważniejszej w myśl literackiej strategii narratora zmiany, a mianowicie pojednania synów Józefa. Ta transformacja zachodzi w dalszej części cyklu i odbywa się w pełnych dramaturgii i emocji okolicznościach. Jej owocem jest nie tylko trwałe pojednanie między braćmi, ale też zachowanie przy życiu całego rodu Jakuba, którego dalsze dzieje zostały wystawione na wielką próbę z powodu panującego w okolicy głodu. Historia Józefa, tak kunsztownie przepełniona elementami dramatu i trzymająca lektora w napięciu i niepewności aż do ostatnich wierszy, kończy się zatem pomyślnie. Wszystkie konflikty, które zawiązywały się sukcesywnie w miarę relacjonowania wydarzeń znajdują swe pozytywne rozwiązanie. Co więcej, lektor ustami głównego bohatera otrzymuje klucz do interpretacji opowiedzianych faktów i zaczyna dostrzegać i rozumieć, iż sukcesywnie opisywane fakty wcale nie były przypadkowe, lecz stanowią misternie utkaną sekwencję zdarzeń, której przyczyną sprawczą jest sam Bóg. A zatem w perspektywie kliku teologicznych komentarzy, które zostały wplecione w newralgiczne punkty narracji, cykl tradycji o Józefie utracił swój pierwotny świecki charakter ${ }^{35}$, który do dziś przeważa w jego większej części, i staje się typowym przykładem religijnego świadectwa o Bożej wierności wobec Izraela, w tym konkretnym przypadku, o życzliwości Jahwe wobec jego protoplastów patriarchów.

Niezmierzona mądrość i opatrzność Boga, która w kolejno prezentowanych tradycjach pozostaje zwykle głęboko zakryta nie tylko dla lektora, ale również dla głównych bohaterów opowiadania, w kontekście całego cyklu objawia się w formie konkretnego planu zbawienia. W obliczu zagrażającego rodowi Jakuba realnego niebezpieczeństwa (klęska głodu), które stawiało pod znakiem zapytania zasadność Bożych obietnic skierowanych do Abrama, Izaaka i Jakuba, jak też los narodu izraelskiego już u zarania jego historii, Jahwe postanowił ocalić wybrane przez siebie pokolenie poprzez jednego z synów Izraela. W tym celu obdarzył Józefa niezwykłymi charyzmatami (zdolność interpretacji snów i umiejętność zarządzania) oraz mądrością, dzięki którym ocalony został nie tylko ród Jakuba, ale także okoliczne narody, łącznie z wielkim Egiptem. Oto

${ }^{35}$ Jak wskazaliśmy wyżej, w odróżnieniu od pozostałych przekazów o patriarchach (Rdz 12-35), a także w odróżnieniu od dodanej do oryginalnej wersji cyklu o Józefie sekcji Rdz 48-50, Bóg niezmiernie rzadko pojawia się w relacji o synu Jakuba. Są jednak i takie miejsca w obrębie narracji, które niespodziewanie i w nienaturalny dla stylu i koncepcji reszty tradycji są przeładowane teologią (39,2-5.21-23; 41,16-25.28.32.38-39; 42,16.21-22.28). Ten fakt podaje w wątpliwość oryginalność tych tekstów i sugeruje ich wtórne redakcyjne pochodzenie. 
główne przesłanie teologiczne, które komunikuje ostateczna wersja historii Józefa (Rdz 37-50) wkomponowana w kontekst poprzednich cyklów o patriarchach. To orędzie lektor odkrywa stopniowo wraz z bohaterami cyklu, a czyni to na dwu zasadniczych płaszczyznach. Pierwszą z nich są komentarze teologiczne ${ }^{36}$, którymi narrator życiowych perypetii Józefa raz po raz tłumaczy zarówno niezwykłą życzliwość, z jaką spotyka się Józef w Egipcie ${ }^{37}$, jak też skuteczność jego kolejnych przedsięwzięć, które pozwalają mu wydostać się z coraz poważniejszych tarapatów $(39,2.3 \cdot 5.21 .23)$. Drugą natomiast jest interpretacja toczących się wydarzeń włożona w usta najważniejszej postaci cyklu. W aktualnej formie historii Józefa ma to miejsce aż dwukrotnie, ale zawsze w tym samym kontekście pojednania się synów Jakuba. Po raz pierwszy teologiczna lektura dziejów pojawia się $\mathrm{w}$ kulminacyjnym momencie opowiadania, tzn. $\mathrm{w}$ chwili, kiedy Józef daje się poznać braciom i szczerze jedna się z nimi (45,5-8). Po raz drugi ten sam motyw powraca $\mathrm{w}$ analogicznej scenie pojednania na końcu cyklu $(50,20-21)$ i jest spowodowany poważną zmianą sytuacji życiowej synów Jakuba (śmierć ojca). W obydwu tych tekstach, które z pewnością zostały pomyślane jako teologiczny klucz dla całej historii Józefa, zostaje jasno wyrażone przekonanie, że za biegiem karkołomnych dziejów patriarchy od samego początku stał Bóg jego ojców - Jahwe (45,5-9). W 45,78a Józef wyraźnie interpretuje to, co się stało między nim a jego braćmi, jako konkretną misję zleconą mu przez Jahwe: „Bóg mnie wysłał przed wami, aby mogło przetrwać wasze potomstwo na ziemi i abyście przeżyli dzięki wielkiemu wybawieniu. A zatem nie wyście mnie posłali, lecz Bóg, który też uczynił mnie doradcą faraona, panem całego jego domu i władcą całego Egiptu".

Czytając ten tekst, nie ma się wątpliwości co do jego teologicznego sensu, gdyż jako pierwszorzędną przyczynę ocalenia rodu Jakuba i całego Egiptu wskazuje nie inteligencję i zaradność Józefa, lecz moc i mądrość Jahwe. Ale od razu uderza niecodzienna specyfika jego formy. Wypowiedź Józefa nie ma bowiem $\mathrm{w}$ sobie nic z charakteru prorockich wyroczni, czy też z narracyjnych komentarzy zawartych obficie w cyklach o patriarchach, które informują o częstych i bezpośrednich ingerencjach Boga w ludzkie dzieje tak, jak gdyby były one czymś zupełnie naturalnym i oczywistym, czymś tak rzeczywistym, jak podejmowane przez ludzi decyzje i plany. Interpretacja zdarzeń włożona w usta Józefa ma raczej formę teologicznej refleksji o charakterze mądrościowym, której

${ }^{36}$ Chodzi tu o różnego rodzaju semantyczne postacie formuły wayəhî yhwh (’ādōnāy) 'eț-yôsē̄p „Pan był z Józefem”, które podkreślają nieustanną Bożą życzliwość w stosunku do syna Jakuba.

${ }^{37}$ Ta życzliwość i zaufanie coraz wyższych przedstawicieli egipskiej władzy: Potifar, przełożony więzienia, przełożony piekarzy, podczaszy faraona i sam faraon, jest, jak wynika z tekstu, owocem inteligencji i roztropności Józefa oraz rezultatem przypisywanej mu powszechnie stałej życzliwości Boga. 
dokonuje się z perspektywy jakiegoś czasu i w oparciu o przeżyte doświadczenia ${ }^{38}$. Misja Józefa jest bardzo szczególna. W przeciwieństwie do innych ważnych postaci biblijnych nie ma on do przekazania żadnego orędzia, lecz winien wypełnić konkretne zadania administracyjne i doradcze na wzór funkcjonariuszy królewskich dworów Bliskiego Wschodu. Poza tym, teologiczna interpretacja dziejów własnego rodu, którą Józef dzieli się ze swymi braćmi, nie jest owocem Bożego (prorockiego) objawienia czy też innego rodzaju nadprzyrodzonej wizji, chociaż idea ta jest głęboko wpisana w treść cyklu (chodzi tu przede wszystkim o tajemne sny, których właściwe odczytanie pozostaje w gestii samego Boga, 40,8; 41,16.25.28.32.38-39), lecz bardzo dokładnej i pogłębionej refleksji nad historią zaistniałych zdarzeń. Inną nowością jest też to, że Józef, mówiąc o Bożej opatrzności i trosce wobec niego i całego rodu Jakuba, nie odwołuje się do jakiegoś szczególnego i jednostkowego wydarzenia zbawczego, które byłoby koronnym argumentem w uznaniu Jego wpływu na bieg historii ${ }^{39}$, ale do, rzec by można, banalnych i zwyczajnych faktów z codziennego życia, które na pozór wydają się być zwykłą i naturalną koleją losu, natomiast w rzeczywistości kreują bardzo logiczny bieg zdarzeń i wskazują na wyraźny plan Boży ${ }^{40}$.

Oczywiście ten zamysł Boży w określonym splocie wydarzeń potrafi odczytać jedynie człowiek wiary, to znaczy ten, kto posiada dar Bożego ducha i jest obdarzony typową dla mędrców przenikliwością umysłu oraz zdolnością do właściwej oceny rzeczywistości. W obszernym cyklu o dziejach synów Jakuba tym człowiekiem jest naturalnie Józef i tylko on. Boży plan zbawienia jest zupełnie niepojęty i zakryty dla braci Józefa, dla jego ojca Jakuba ${ }^{41}$, a nawet dla symbolu wschodniej mądrości - królewskiego dworu w Egipcie ${ }^{42}$. Najwy-

${ }^{38}$ Wniosek ten potwierdzony jest również przez dość szczególną sapiencjalną terminologię obecną w tych wierszach. G. W. Coats, The Joseph Story and Ancient Wisdom. A Reappraisal, CBQ 35 (1973), s. 285-297; J. King, The Joseph Story and Divine Politics. A Comparative Study of a Biographic Formula from the Ancient Near East, JBL 106 (1987), s. 577-594; H. White, The Joseph Story. A Narrative which "Consumes" its Content, Sem 31 (1985), s. 46-49.

${ }^{39}$ Dla porównania dzieje Abrahama, Jakuba, Mojżesza, ludu izraelskiego w Egipcie oraz w drodze do Kanaanu, czy też historie z epoki sędziów, proroków i królów (np. ratunek $\mathrm{w}$ chwilach klęsk naturalnych lub militarne zwycięstwa odniesione nad silniejszym nieprzyjacielem) ciągle odwołują się i opierają na konkretnych i wyraźnych ingerencjach zbawczych Boga.

${ }^{40}$ R. E. Longacre, Joseph, s. 3nn; J. L. Ska, La scoperta del disegno di Dio, s. 129-131.

${ }^{41}$ Wniosek ten potwierdza nawet późniejszy redaktor cyklu, który uzupełnił oryginalny kształt historii Józefa o wizję Jakuba w 46,1-4. Tekst ten przekonuje starego patriarchę oraz samego lektora o tym, że wszystko, co się dzieje, jest wolą Jahwe.

${ }^{42}$ Te same wydarzenia bracia Józefa interpretują w zupełnie innym świetle $(42,21-$ -22.28; 44,16; 50,15-18), chociaż i oni widzą w nich rękę Boga. Trapieni wyrzutami sumienia we wszystkim, co spotyka ich w Egipcie, widzą objaw Bożego gniewu i zasłużoną karę za niegodziwość, której dopuścili się w przeszłości poprzez nazbyt surową zemstę na swym 
raźniej tę teologiczną wersję zdarzeń oraz kontrast i rozbieżność w sposobie jej interpretacji widać w kluczowym dialogu cyklu $(45,3-13)^{43}$, w którym Józef przeciwstawia plan Boży planom ludzkim oraz wyjaśnia swym przestraszonym braciom sposób, w jaki Jahwe posłużył się ich zemstą i niegodziwością, aby zrealizować swój plan zbawienia wobec całego domu Jakuba. Bracia myśleli, że sprzedając niepokornego i rozkapryszonego krewnego kupcom udającym się do Egiptu, poślą go na tyle daleko od domu, że definitywnie pozbędą się niewygodnego konkurenta do ojcowskich przywilejów. Tymczasem, według Józefa, to nie oni, ale sam Bóg kierował od początku biegiem zdarzeń, wykorzystując dla realizacji swej zbawczej woli zarówno partykularyzm Jakuba, pychę Józefa, jak i niegodziwość i nienawiść jego braci. Dlatego też Józef ani przez chwilę nie czuje urazy do swych braci i nie pała żądzą zemsty za doznane za ich przyczyną upokorzenia, gdyż we wszystkim, co go spotkało, odnajduje palec Boży ${ }^{44}$. W gruncie rzeczy to nie oni, ale Jahwe kierował losem jego życia. Co prawda w Boży plan zostały również wpisane najbardziej negatywne emocje i żądze ludzkie (niesprawiedliwe preferencje, wyniosłość, pycha, zemsta, nienawiść, strach), ale stanowiły one jedynie drogę do realizacji jasno określonego i pozytywnego celu, którym było ocalenie wielu rodów, ludów i narodów. Bóg bowiem, i to jest najważniejsze a jednocześnie najbardziej spektakularne teologiczne orędzie historii Józefa, nie jest Bogiem śmierci, nienawiści, przemocy i słabości, lecz Panem życia, przebaczenia, sprawiedliwej i troskliwej władzy oraz potęgi i mądrości w działaniu. To dlatego posłał Józefa do Egiptu, aby

bracie oraz oszukanie starego ojca. Bożego planu zbawienia, pomimo niekwestionowanej mądrości, nie jest w stanie odkryć i zrozumieć również faraon oraz jego mędrcy i urzędnicy, choć przekonani są co do Bożej proweniencji mądrości i roztropności Józefa (41,37-43). W. Brueggemann, Gen 50,15-21. A Theological Exploration, VT.S 36 (1985), s. 4-53.

${ }^{43}$ Te same wątki powracają zresztą w dialogu Józefa z braćmi, który zamyka dzisiejszą wersję cyklu i całą księgę Rodzaju (50,15-21). Również w tych wierszach Józef radykalnie przeciwstawia plan działania braci oraz zamysł Boży. Zamiarem synów Jakuba było surowe ukaranie Józefa, natomiast wolą Jahwe było ocalenie wielkiego narodu, dlatego też swą nadprzyrodzoną mocą dokonał niezwykłej transformacji zła w dobro $(50,20)$. W tych wierszach wyraźnie odzwierciedla się mądrościowa teza, która charakteryzuje bardzo wiele tekstów wchodzących w skład tzw. ksiąg dydaktycznych, por. np. niektóre przysłowia (Prz 16,2.9; 19,21), treść księgi Koheleta, czy też teologiczną refleksję nad prawdziwością i aktualnością zasady odpłaty zawartą w księdze Mądrości (Mdr 1-5).

${ }^{44}$ Wydaje się, że za słowami Józefa stoi niewzruszone przekonanie patriarchy, że gdyby nie zemsta braci, to nie doszłoby do skutku ani jego wywyższenie w Egipcie, ani, co ważniejsze, ocalenie rodu Jakuba w okresie dotkliwego głodu. Tego rodzaju interpretacja historii jest kolejnym teologicznym zabiegiem narratora, który usiłuje podkreślić niezwykłe uzdolnienia Józefa a jednocześnie ukazać go jako charyzmatycznego i natchnionego Bożym duchem mędrca. A. Bonora, Ricerca di Dio nella storia di Giuseppe (Gen 37-50), w: Atti della XXV settimana biblica italiana. Quaerere Deum (Brescia 1980), s. 67-88; R. E. Longacre, Joseph, s. 43; G. Wenham, Genesis 16-50, s. 428. 
«zachować życie swych wybrańców i ich potomstwa» $(45,5.7 ; 50,20)$, a w konsekwencji w przedziwny sposób doprowadził do pojednania, solidarności i niezwykłej konsolidacji w szeregach potomków Jakuba, którzy w przyszłości utworzą jeden silny naród.

DIO E L`UOMO NELLA STORIA BIBLICA DI GIUSEPPE (GEN 37-50)

\section{RIASSUNTO}

Il ciclo delle tradizioni sulle vicende di Giuseppe e dei suoi fratelli (Gen 37-50) appartiene ad una delle piu belle e più lavorate testimonianze della letteratura biblica. Nello stesso tempo queste tradizioni sono molto complesse ed originarie dal punto di vista redazionale e teologico. La versione attuale di esse è frutto di un lungo processo di redazione ed e pieno delle successive correzioni ed elaborazioni teologiche. La storia di Giuseppe fu perfettamente inserita nella lunga saga dedicata alla tribù di Giacobbe (Gen 25,1-50,26), cosí che oggi funge dal epilogo delle tradizioni sui patriarchi di Israele. Contemporaneamente i testi su Giuseppe divergono notevolmente dalle tradizioni su Abramo, Isacco e Giacobbe sia sotto aspetto letterario, sia quello teologico. Quale dunque e la provenienza di questi racconti cosí pittoreschi? Quali sono i vincoli che legano le tradizioni su Giuseppe con gli altri cicli sui patriarchi? Ed, in fine, quale è il ruolo della storia di Giuseppe nel contesto odierno del libro di Genesi? 